\title{
ERRIER BOGS,
}

क्रु० 0

a) 2 \%०

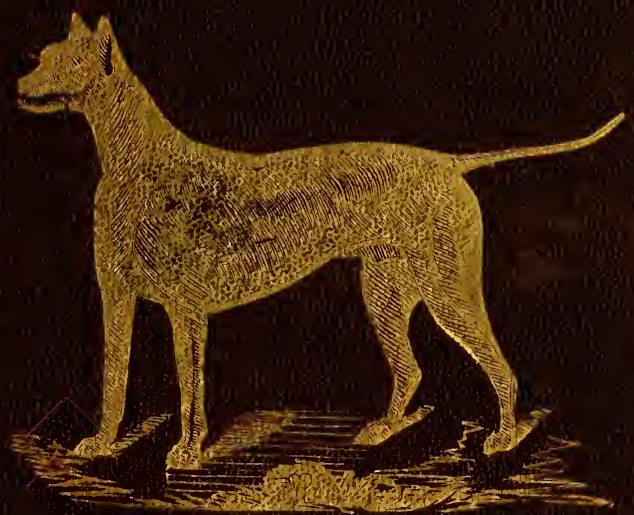

Rn

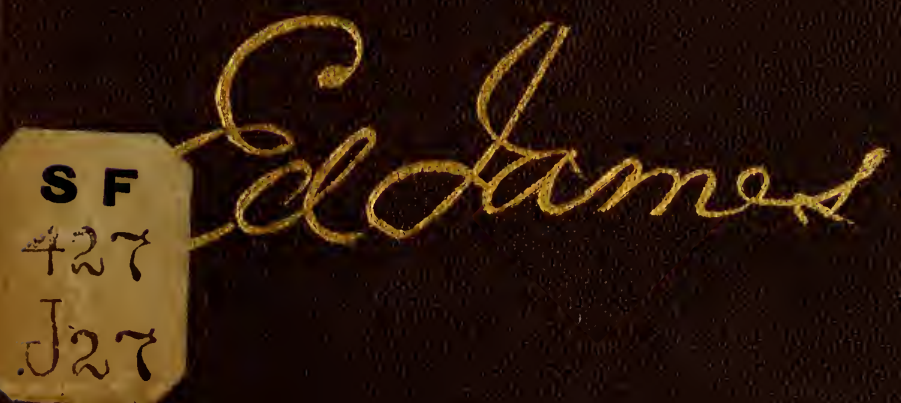




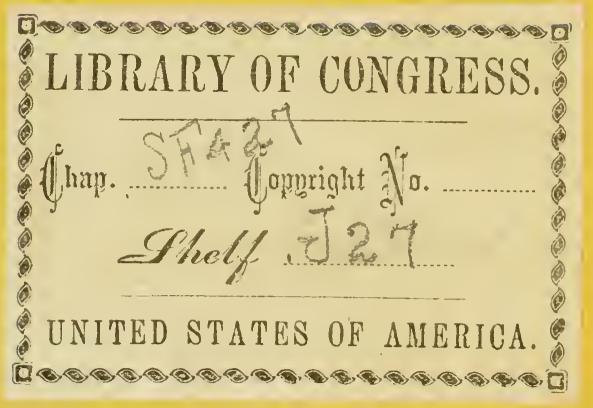







Eclamex 


\section{TERRIER}

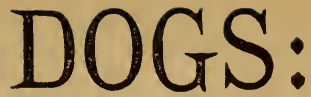

SHOWING THE BEST METHODS OF

BREEDING, REARING, FEEDING, CROPPNG, PHYSICING,

CURE OF DISEASES, ETC.,

WITH A DESCRIPTION OF THE

POINTS AND PROPERTIES OF THE BULL DOG, BULL TERRIER, BLACK AND TAN, SCOTCH, SKYE AND TOY TERRIERS, ITALIAN GREYHOUND, PUG DOG AND KING CHARLES SPANIEL;

ALSO,

RATS AND RAT KILLING, WITH

CANINE, RATTING AND BADGER BAITING RULES, AND TRAINING DOGS FOR THE PIT;

TOGETHER WITH THE

ART OF LEARNING DOGS TRICKS.

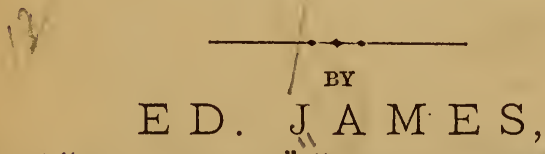

AUTHOR OF "THE GAME COCK," "MANUAL OF SPORTLNG RULES," ETC.

PUBLISHED BY $\triangle$

ED. JAMES, 88 AND 90 CENTRE STREET, NEW YORK. NEW YORK CLIPPER BUILDING.

$$
\text { I } 873 \text {. Price, } \$ 1 \text { “ }
$$




\section{Second Edition.}

\section{SF427}

J 27

Entered according to act of Congress, in the year 1873, In the office of the Librarian of Congress, at Washington.

Copyrighted at Stationers' Hall, Ĺondon, England. 


\section{PREFACE.}

There are few households indeed where we do not find a dog of some kind. Some are kept for use, others for amusement. While almost everyone has a general knowledge of what dogs should be, few understand the points which render them valuable. To those who own dogs or intend to purchase, it would be well to carefully peruse this little volume, which combines conciseness with practicability and useful information. Dog like other flesh is liable to ills of various kinds, and they need looking after from birth till death. How to do this properly, with remedies for their various diseases, is herein given. Canine contests may not suit the majority, but "everybody to his fancy." No one, however, can consistently find fault with encouraging the destruction of that detestable and destructive animal known as the rat. For this reason the Canine and Ratting Rules are introduced, as also the mode of Training dogs for these purposes. Those having pet dogs will find an interesting chapter upon the method of learning them various Tricks, and it is hoped and believed that this volume will find its way wherever it will be of use, 


\section{CONTENTS.}

TERRIER DOGS, ETC.

How to Breed Dogs........................... 7

Removing Dewclaws........................... 8

Cropping Terriers................................ \& 8

THe Bull Dog.

A Little of All Sorts......................... 9

His Appearance and Courage...................... io

Points and Properties............................. II

Principal Breeders.............................13

The Bull Terrier-Points and Properties................... I5

THE BLACK and TAN-Points and Properties............... I6

THE ROUGH TERrIER-Points and Properties................. I3

The Skye Terrier-Points and Properties.................. is

The Italian Greyhound-Points and Properties...............20

THE PUG DOG-Points and Properties.... ................

King Charles Spaniel.................................. 22

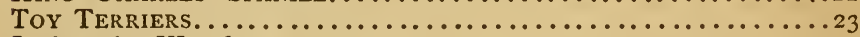

Jacko, the Wonder.....................................24

Dog Shows..........................................25

Training for the Pit....................................... 26

Dog Fighting Rules....................................27

English Dog Fighting Rules.............................28

Rat Killing Rules...................................29

Badger Baiting Rules......................................

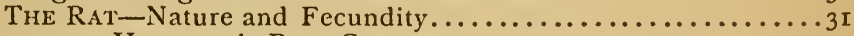

How much Rats Consume......................... 32

About Ferrets.................................. 33

What Cats and Traps will Do.......................... 33

The Rat's Greatest Enemy......................... 34

Learning Dogs to Kill Rats......................... 34

ART of LEARNING Dogs Tricks-To Leap ; To Walk Erect …36

To Dance; To Sit and Lie Down; To Beg.............37

To Speak For It : To Fetch and Carry $\ldots . . \ldots \ldots \ldots \ldots . . .38$

To Bring his Tail in his Mouth...................... 3 ?

To Stand on his Head and Walk on his Hind Legs.... 40

To Sing ...................................40

To Feign Death: The Lump of Sugar Trick ........... 4 I

Diseasas AND THEIr CURE-Hydrophobia...................... 42

Inflammation of the Eye. ..................

Cataract or Scum ...........................

Inflammation of the Bowels....................

Dumb Madness........................... ${ }^{2}$

Canker in the Ear..........................

Jaundice. ............................ ${ }_{43}$

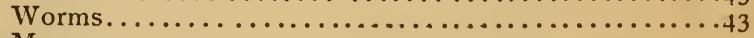

Mange....................................

Distemper.................................

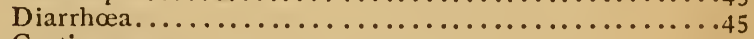

Costiveness................................

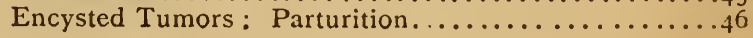




\section{TERRIER

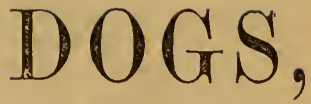

$\mathrm{E} \mathrm{T}$.

HOW TO BREED DOGS.

Do not be satisfied with the appearance of the Dog or Bitch which you intend to breed from. Ascertain their pedigree as far back as possible, say at least four generations. The male should be not under two years old and the female at least fifteen months. The male, if in health and well used is not unfit to breed with, till his eighth year, the female under like circumstances until her sixth year. They should both be in perfect health. The female goes with young two months and three.days, and has from four to a dozen young at a birth. The pups are born blind, and their eyes open about the tenth day. The female should not be permitted to breed oftener than three times in two years, nor to rear more than five puppies. The pups should not be suckled longer than six weeks. After weaning the pups will feed voraciously, but should not be given as much as they.will eat or they will surfeit themselves. Their diet may consist of well boiled oatmeal porridge, mashed potatoes, with skim milk, or new milk, to dilute the mess; give it cool, and do not add the milk until the mess be cool. Feed three times a day. Give the food fresh and keep the vessels clean. Iet the pups have a bed of clean straw over pine shavings or pine sawdust, the turpentine contained in the wood banishes fleas.

Examine the puppies occasionally to see whether they are lousy; a decoction of tobacco destroys the vermin.

Let there be a supply of fresh water always within their reach, and let them have an open yard in which they may disport themselves. If you hav'nt a grass plot, get some nice fresh grass cut twice or three times a week, accessible to them. The dog is the best physician in his own sickness, and will resort to the grass with much satisfaction if his stomach be out of order. At about four months 
old, the first set of teeth, or milk teeth, begin to drop out, and are replaced by the permanent set, which change is complete between the sixth and seventh month. The tusk? have acquired their length about the twelfth or thirteenth month. At about two years old, a yellow circle makes its appearance around the base of the tusks, which gradually develops itself, with more and more intensity, until the third year. About this time, the edges of the front or cutting teeth, begin to be worn down, and the little nick on the crown of the lateral incisors disappear. As the fourth year approaches, the tusks lose their points, and the teeth present a gradual progress of decay, until the fifth or sixth year, when the incisors begin to fall and the tusks become discolored over their entire surface,. At his eighth year a few gray hairs will show themselves around his eyes and the corners of his mouth. These appearances increase in intensity to the eleventh or twelfth year.

\section{REMOVING DEWCLAWS.}

It frequently happens that puppies are born with a fifth toe upon the hind foot; this is called a dewclaw. This should be taken off between the third or fourth week. The modus operandi is as follows: Let the pup be firmly held by one person and the second person taking a pair of large, sharp scissors, after having felt for the proper place to cut, proceed to cut off the extraneous member-do this unhesitatingly and with firmness. Some think this inhuman, but the pain is momentary and the tongue of the dam will soon heal it.

\section{CROPPING TERRIERS.}

In cropping a Black and Tan, or any other terrier, the following directions should be observed: Draw the ears over the head until the points meet; with a very sharp pair of scissors, cut both points off to the length you desire; then with a single cut to each, from below upwards, cut away the hinder portion of the flaps of the ears up to the point. In a week they will be all healed up. The tail of a well bred pup should never be meddled with; and if the dog. be badly bred, and his tail, consequently, coarse, he is not worth keeping. 


\section{A LITTLE OF ALL SORTS.}

\section{Useful Informatton for Owners of Dogs.}

Staggers and Fits generally happen in warm weather. Throw water on them, if convenient. If not, bleed in neck if you have lancets. If not, with your knife slit the ears, which you can cause to adhere together again; or run your knife across two or three bars next the teeth. Bitches coming off heat are more subject to this than dogs in good health.

To make a bitch inclined to copulate give seven drops tincture of cantharides twice a day till effect is produced, which generally takes about six days.

To make a dog fine his coat give a tablespoonful of tar in oatrieal. Make bolus.

For wounds apply a poultice for a day or two then ap- . ply Frier's Balsam covering up the place.

To make a Seton, take a dozen or two strands of a horse's tail, plait them, rub blistering ointment on them. Pass it through two or three inches of the skin with a curved surgical needle. Tie the ends together. Move daily.

If a dog is poisoned, give teacupful of castor oil. After he has vomited well continue to pour olive oil down his throat, and rub his belly.

To reduce the time a bitch is in heat, give her a little nitre in water, and a dose of calomel, four grains or thereabouts, followed by salts or aloes.

Bilious Fever, is caused by want of exercise and too high feeding. Calomel, six or eight grains; or in an obstinate case, turpeth mineral or yellow-mercury, six to twelve grains, in a bolus.

To ReMOVE Fleas. - Scotch snuff steeped in gin is infallible, but must be used with great care, and not above a teaspoonful of snuff to a pint of gin, as the cure, if overdone is a deadly poison.

For Lice use a small quantity of mercurial aintment, reduced by adding hog's lard to it, say an equal quantity, rubbed along the top of the dog's back never fails. The greatest care must be taken to keep the animal warm.

Bones given to dogs habitually not only clean the teeth; but aid in their formation, and also increase the general bealth of the whole system. 


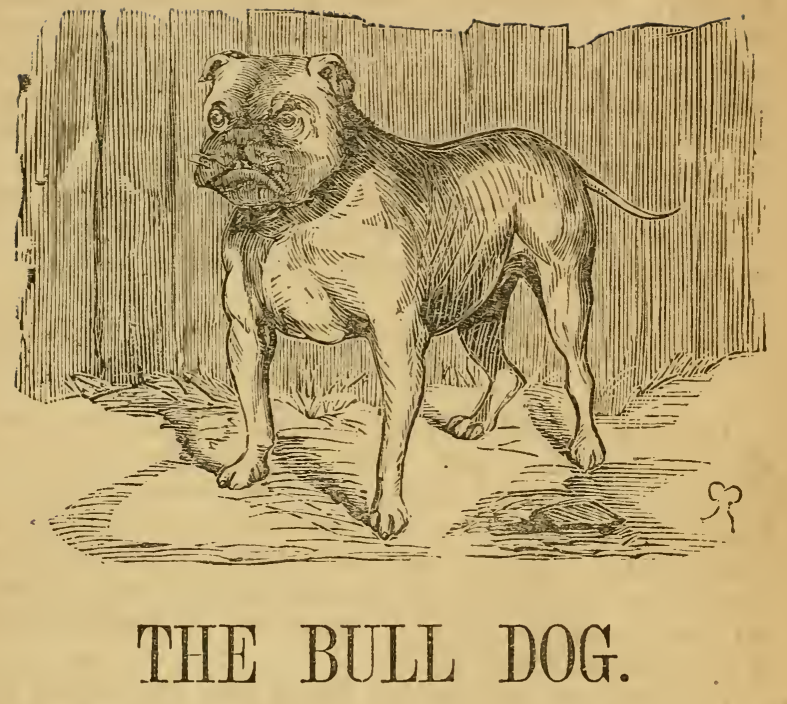

HIS APPEARANCE AND COURAGE.

The Bull Dog takes his name from having in olden times been employed in fighting the bull. He is low in stature, deep chested and strongly made about the shoulders and thighs, the muscles of both. of which are extremely developed. His head is broad, his nose short and under jaw projects beyond the upper which gives him a fierco and disagreeable aspect. His eyes are distant and prominent and have a peculiar suspicious-like leer which with the distension of his nostrils gives him a contemptuous look, and, from his teeth being always seen, he has the constant appearance of grinning when he is perfectly placid. $\mathrm{He}$ is the most ferocious and unrelenting of the canine tribe, and may be considered courageous beyond every other creature in the world, for he will attack any animal, whatever his magnitude may be. The brain of the bull dog is sensibly smaller than that of any other animal, and it is owing to this that he is inferior to all other species in everything relating to intelligence. He is scarcely capable 
of any education, and is fitted for nothing but combat and ferocity. Nothing can exceed the fury with which the bull dog falls upon all other animals, and the invincible obstinacy with which he maintains his hold. Whenever a bull dog attacks any of the extremities of the body it is universally considered a mark of his degeneracy from the original purity of the blood. The ligaments of the bull dog, are not considered at their full strength until he is at least two vears old, and some say they are not in their prime until they have attained four or five years.

\section{POINTS AND PROPERTIES OF A PERFECT BUTL DOG:}

The ears should be very small and should be placed on the top of the head. They should be either "rose," "button" or "tulip" ears. The "rose ear" folds at the back and the tip laps over outwards, exposing part of the inside. The "button ear" only differs from the "rose" in the falling of the tip, which laps over in front hiding the interior completely. The "tulip ear" is nearly erect, and is the least desirable form.

The skull should be very large, and the cheeks should extend well beyond the eyes. Breadth of the skull should be in comparison to length. The forehead should be well wrinkled, and not prominent as in the "King Charles" Spaniel.

The eyes should be as nearly black as possible. The shape of the opening of the lids should be quite round. The eyes should be moderately large, and should be quite in front of the head, as far from the ear and as near to the nose as possible; very far apart, but not so far as to interfere with the prominence of the cheeks, and neither prominent, nor deeply set in the head. The corners of the eyes should be at right angles to a line drawn down the centre of the face.

The "stop" is an indentation between the eyes. It should extend some considerable distance up the head.

The face, measured from the front of the cheek bone to the end of the nose, should be very short, and this point cannot be carried to too great an excess. The wrinkles should be deep and close together. The muzzle should turn upwards.

The covering of the teeth, which should not be seen 
when the mouth is shut. The nose should be large and black.

The breadth at the termination of the jaws should be as great as possible, and the lower jaw should project considerably in advance of the upper one, so that the nose is very much set back. The lower jaw should turn upwards.

The neck should be moderate in length, of considerable thickness and should be well arched at the back.

The chest should be very great in width and should be deep and round.

The body should be very broad at the shoulders and comparatively small at the loins. There should be a fall in the back behind theoshoulders and the spine should rise at the loins, falling again very much towards the stern, and forming an elegant arch. The ribs should be well rounded.

The stern should be moderate in length. A slight crook is no objection, but a screwed or notted stern is not to be desired. A greater length may be allowed, provided the tail curl at the end, and form what is called a "ring tail." A little thickness at the root is an advantage. The carriage of the stern should be downwards, and the dog should not be able to raise his stern above the level of his back. The situation should be low down at the insertion.

The fore legs should be very thick in the calves, rather bowed in shape, (more so than the hind legs) but not so as to make the back appear long.

The hind legs should be moderate in length, but greater than that of the fore legs, so as to elevate the loins. The hocks should approach each other, which involves the turning out of the stifles.

The fore feet should be moderately round and well split up between the toes, they should be straight, that is, neither turned outwards nor inwards, and should be rather small in size.

The hind feet are not expected to be so round as the forefeet, but they should not be long like a terrier's, and they should be split up between the toes. They should be turned outwards and rather small in size

The color should be "whole," that is, unmixed with white; unless the dog be all white, which is, in that case, considered a "whole" color.

The tint should be either red, red-smut (that is red with black muzzle), fawn, fawn-smut, fallow, fallow-smut, brindled, white, or blue fawn (that is fawn with blue muzzle). 
A dog may be pied with any of the above colors, but a "whole" color is to be preferred.

Proportion-No property should be so much in excess as to destroy the general symmetry of the dog.

Carriage-The dog should roll in his gait. He generally runs rather sideways. His hind legs should not be lifted high as he runs, so that his hind feet seem to skim the ground.

Weight-This may be from about fifteen to sixty pounds.

\section{PRINCIPAL BREEDERS OF BULL DOGS.}

The English Bull Dog is gradually disappearing from the animal kingdom. Jemmy Shaw the famous dog fancier and ex-pugilist of London, Eng., about thirty years ago had a white dog called "Tumbler" who was a descendant of the breed of dogs, known as the Tumbler breed, or Screw-tail dog, he was acknowledged by the fancy to be a first class high bred dog. Jim Burns, a well known English pugilist, had a brace of bulls named Crib and Rosa which were also celebrated for their high breed. The Clerkenwell Green dog, all white and not very large, was in great demand a few years later for stock purposes, but according to Harry Jennings' opinion, the handsomest bull dog in or near London was that owned by Jack Gill, of Deptford, this dog was a brindle and white and was a Tumbler breed, weighing about twenty-one pounds. The late George Moore formerly of Liverpool, but for a long time a resident of New York, owned one of the highest and best bred bull dogs of his time. There may be a few of the old stock left, but they are "few and far between." 

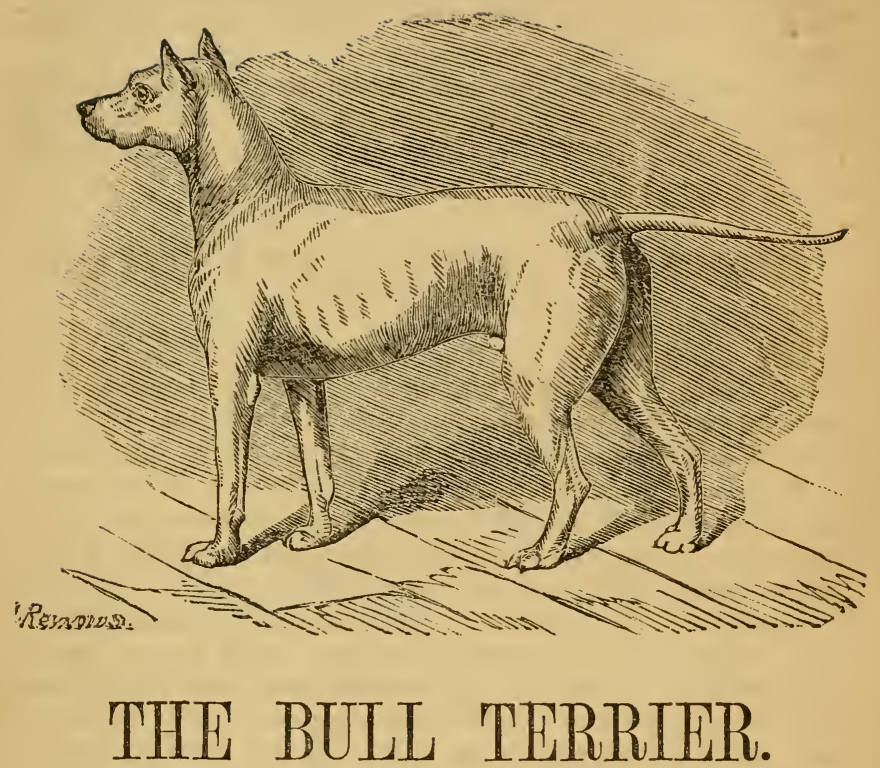

The Bull Terricr is bred from the Bull Dog and English Terrier Hound, the last named being used for bringing out the fox when he is secreted in his hole and the Fox Hounds cannot get at him, and is noted for extraordinary speed, scent, and gameness, in short, he will face anything.

The first cross of Bull Terrier is generally too much like the Bull Dog, but the second shows in perfection all the attributes required for the purpose the Bull Terrier is used.

The best breed of Bull Terriers are those that come from the North of England, Yorkshire and Staffordshire. They are used for fighting, rat killing, coon, badger, and bear baiting, and make perhaps the best watch dogs. The Bull Terrier is becoming a more domestic and tracta. ble successor to the Bull Dog uniting, as he does, the most desirable qualities and presenting a far more inviting appearance.

Whatever objections may be raised to some of the uses 
terriers are employed in, dogs will be dogs and "delight to bark and bite," as Watts the psalmist has to truthfully sung.

No one however has such a passionate love for that detestable "varmint" the rat, as to object to the destruction of the same. It is as natural for a good dog to kill rats as for a cat to kill mice.

\section{POINTS AND PROPERTIES OF A PERFECT BULL TERRIER.}

His head should be long, the muzzle sharp, the jaw level-not underhung, which is a disfigurement and also prevents a dog punishing his adversary. The under jaw should display great power, and the neck should be long.

The chest is wide, the shoulders sloping and powerful, the loins and back strong, the hind quarters and thighs muscular. The tail should be fine and sting-like but not bare, carried gaily but not "hooped."

The fore legs should be straight with a slight angle at the pastern. The bone of the leg must be as large as possible and the muscle of the fore arm as well as the tendons of the pasterns and toes, proportionably strong. If the foot is not perfectly straight, it must turn in, not out. In shape it should be round and cat-like, but very highly arched toes are apt to give way. Sole hard and thick. The hind quarters must be as strong as possible, wide as well as deep. Bone of pastern strong and large; hocks strong and straight.

The coat throughout is fine and short, and it should lio smoothly as in a well dressed racehorse. Pure white, with a black eye and nose, is the most approved color, but white with colored ears or a patch on the eyes is highly appreciated. As in the Bull Dog the color should bo "whole" and, when spotted, correspond with the colors of the Bull Dog.

His weight varies from twelve up to thirty-five pounds or more.

His appearance resembles that of the terrier, except that he is wider across the skull and possesses more strength and stamina. 


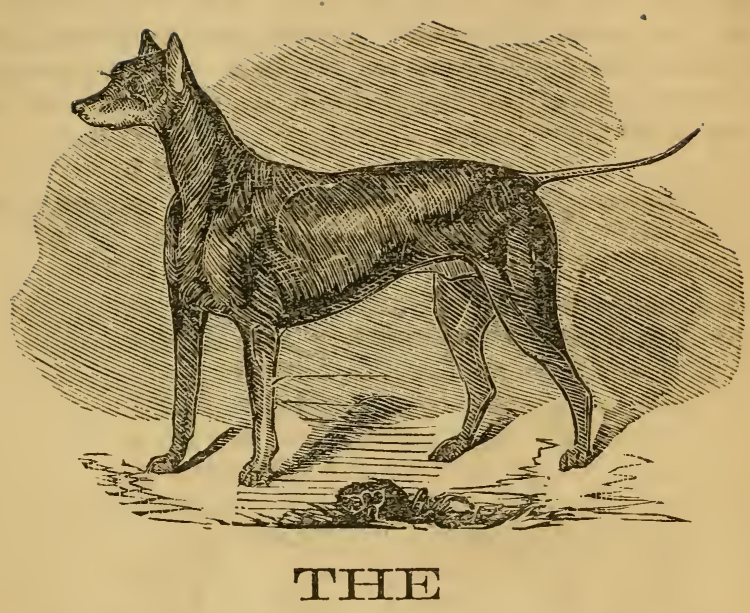

\section{BLACK AND TAN TERRIER.}

POINTS AND PROPERTIES.

The Black and Tan English Terrier should have a long fine muzzle, not underhung, but, if anything, the upper jaw projecting over the lower. The skull shorld be flat and narrow between the ears; the eye must be small and black; the nose black; the ears, if not left on, must be well cropped, erect, and long; if entire, they should be small, not tuliped, and free from any $\tan$ behind.

The neck tapering, muscular, and well cut under the lower jaw.

The shoulders deep, and well set back.

The loins strong, ribs round, and the back ribs deep, the body well knit together.

The legs straight, and the feet round and small.

The tail must be fine, carried straight and not curled.

The color, which is a principal point, must be raven black, with rich mahogany tan, well penciled on each toe; the tan should be clear and free from any admixture of black. Above the eyes there should be a distinct spot of 
tan. The body should be black, with a rich tan on the fore legs half way up them. The breast should have two distinct marks of tan. The jaw should also be well tanned up the gullet, and the cheek divided, having a small tan spot a little less than that over the eyes. The upper jaw should also be nicely tanned and run in conformity with the tanning on the lower jaw. The hind legs should be perfectly free from tan on the outside, but on the inside there should be some tan. The vent should have a small tan spot, and there should also be tan half way up the tail.

The weight varies from ten to twenty-five pounds.

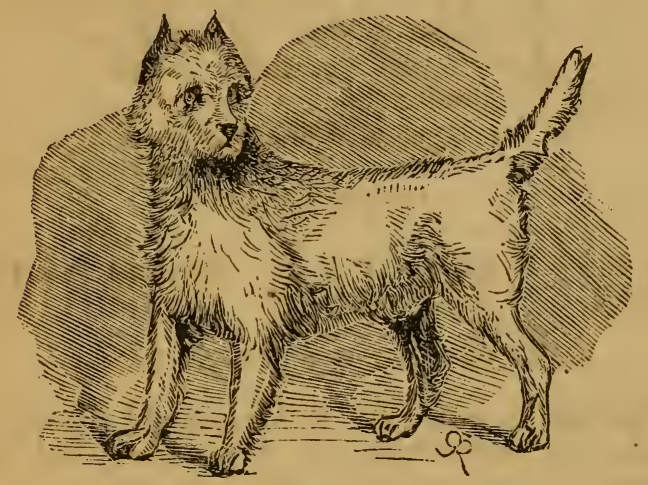

\section{THE ROUGH TERPIER.}

Rough Terriers are no doubt all descended from the broken-haired Scotch dog, with which all must be familiar, but whether the modern silken-hair has been developed by crossisg with the Maltese, or by selection is a moot question. In general shape this dog resembles the smooth variety, but he is slightly longer in frame, and not so elegant in his proportions. The chief peculiarity is in coat and color. The roughness of the coat about the muzzle and face makes the head look larger, and takes off a good deal from the lively look so remarkable in the smooth dog. The modern Rough Terrier is of a blue color, with rich fawn (approaching to a tan) legs, the under part being 
all of the latter color. The tail is carried higher than that of the smooth dog. In the old-fashioned strain the colors are either grizzled, black, with pale tan spots, or generally of a grizzled black-brown, sometimes quite gray and constituting the pepper-and-salt color. Sometimes the broken-haired dog is white, more or less marked with blue or some other color, but the less the better.

\section{POINTS AND PROPERTIES OF A PERFECT ROUGH TERRIER.}

The points of the Rough Terrier are the same as regards shape and make as the Smooth English Terrier; but the coat differs in being long, and of three different shades, that on the back being a blue slate; the face, head and legs a silky silvery fawn; the whole undermined by short tanned hair. The older the dog the more silvery he gets.

The Scotch Terrier is also the same in shape. . His color may be pepper or mustard, or pepper and mustard; in each case more or less mixed with salt.

The Toy dog of these strains is the same in all but weight, which should not exceed seven pounds, the smaller the better.

\section{THE SKYE TERRIER.}

POINTS AND PROPERTIES.

This dog is, with the exception of the Turnspit, and his foreign representative, the Barbet, the longest of all dogs in proportion to his height. From the nose to the tip of his tail, when extended, the Skye should measure at least three times its height, and sometimes it is met with three and a half times as long. At the same time its coat is so developed that its shape is nearly very like the door-mat to which it is so often compared-ears, legs, and tail all verging in one mass, with the exception of the tip of the latter, and of the feet. In a well coated specimen the eyes are only to be guessed at, and even the nose is often obscured, but generally they are each more or less visible on a close inspectios.

The head looks large from the profusion of hair with 
which it is invested but it is not really so. Its shape is not easily got at, but it is somewhat wide, while the neck is unusually long. The eyes, which are, from the same cause scarcely visible, are found, on separating the over-hanging hair, to be keen, expressive, small, and generally of a dark color, either black or.brown, as are the nose and palate. The ears are of gocd size, that is, about three inches long, clothed thickly with hair, which should mingle with that of the face and neck, and should fall, but not quite so close to the cheek, owing to the quantity of hair by which they are surrounded. Many breeders, however, prefer the prick ear, asserting that the strains possessing it are harder and better at vermin. The mouth must be level, with a large and black nose.

The body is too much coated to show its shape, and the form of the shoulder and backribs can only be ascertained by handling.

The.fore legs are generally more or less bandy; there are no dewclaws, and the feet are not very strong, having a tendency to flatness, and thinness of the soles. Tail long, and carried horizontally, but with a sweep, so that the tip is a little below the level of the back. Weight from ten to eighteen pounds, the bitches being nearly as heavy as the dogs-perhaps about two pounds less.

The colors most fancied are steel with black tips, fawn with dark brown tips to the ears and tail, dark slaty-blue (slightly grizzled, but without any absolute admixture of white) black, and pure fawn-the order named being in accordance with the value of each. The hair should be long, straight, and shining like that of the tail of the horse, any appearance of silkiness, wooliness, or curl being to be avoided, excepting on the top of the head, where it may have a slight tendency to the first named condition. 


\section{THE ITALIAN GREYHOUND.}

All authorities unite in the opinion that this beautiful little dog must be an English smooth greyhound in everything but size, which is tantamount to stating that it must be one of the most graceful, or, perhaps, the most graceful and racing-looking creature on the face of the earth.

It is neither more nor less than a small greyhound, for which Italy was celebrated, and which perhaps was originally bred as a distinct breed. It must have become dwarfed from climate or constant "in-breeding," but it has never been in any way deformed by the means adopted to decrease its size.

\section{POINTS AND PROPERTIES OF A PERFECT ITALIAN GREYHOUND.}

The head should be wide behind, and larger in circumference if measured over the ears than over the eyebrows. The jaw should be very lean, with a good muscular development of the cheok. The eye of the Italian variety, however, should not be so large or full as that of the English dog.

The ear of the Italian should be exceedingly small and falling flat, except when the animal is animated. It may then be slightly raised, but never pricked.

Blue and fawn are the favorite colors; the latter should be of an auburn hue. Various colors, however, are fashionable for a time and then fancy changes. At one time cream colored dogs commanded the highest price, then white with black nose. At one time black muzzles were in vogue; and we believe they are preferred at the present time, and parti-colored dogs are not thought much of. When these dogs are self-colored, they should be free from any white, and this may be predicated of every description of dog or hound. Fawn dogs should have black toe-nails. All of the breed should have very glossy coats and a compact form. The tail should be very fine, and though coated, and not bare or showing the caudal vertebræ, it should be void of all roughness.

The weight must not exceed eight or nine pounds, and 
the dog is valuable in proportion as he weighs less than this. Specimens have been bred, which, at maturity, did not reach five pounds, but they were very delicate and shy. Some of the best shaped and most perfect greyhounds of this discription have reached from fourteen to eighteen pounds, and at this weight they are certainly more robust than the more valuable dwarfs, occasionally becoming fat and losing the beautiful lines of their kind. The bitches are much less than the dogs.

It has been crossed in England with the small bullterrier with advantage, and the produce displayed no delicacy and lost none of its courage.

Although the pure Italian greyhound is generally delicate and nervous, it now and then displays wonderful affection and fidelity.

\section{THE PUG DOG.}

The pug dog between the years 1836-46 was the rarest breed in Great Britain. The old and absurd system of cropping off the whole of the ears prevailed, and this cruelty was excused because it occasioned that wrinkling and puckering of the forehead considered essential in a pug dog.

\section{POINTS AND PROPERTIES OF A PERFECT PUG DOG.}

The true English pug should be of a fawn or putty color, devoid of any smut approaching blackness. Clearness and purity of color are essential, so as to render the various markings as clear and sharp in outline as possible. The dog should stand on short legs, as straight and well made as a foxhound, but with long "hare feet", the toes well split up. His head should be round and the forehead high and monkey like; nose short, teeth level, jaw square. The eye should be full and black; the ears are small, silky, black, and close to the head. A black mole should be clearly marked on each cheek, with three hairs in each. The mask should be black and positively marked with well developed wrinkles in the skin; the neck should be strong 
and thick, devoid of all locse or puckered skin. The chest should be broad, the back and loins wide and strong, and a black line or "trace" should run down the back to the end of the tail. The tail should be tightly curled over the side or hip, having a second curl, and the point coming out. The ribs should be round.

A narrow or pointed nose is a very great disfigurement; so is a woolly or dead coat. The coat should be sleek and shining, short, and soft to the touch. Round feet are also bad, so are white toes, or indeed white anywhere. If the black of the mask melts gradually into a grey, and is softened until it mingles with the fawn, the dcg loses much of its value.

\section{KING CHARLES SPANIEL.}

The King Charles is now always either black and tan without white, or mixture of these colors in handsome patches, the tan spot over the eye in the latter case being always an important feature. In the time of Charles II, from whom the dog gets his name, the color as shown by Vandyck was liver and white, which color was in vogue until the present century, when the black and tan superseded it, and is now considered the specialty of the breed. Nor is the modern shortness of face of old standing when carried to the extreme which now prevails. Vandyck's dogs are quite sharp-nosed, and those of the present century were at least only half way on the road to the state in which they are now exhibited, with faces like those of the bull dog. At present the dog should weigh about seven pounds (not more than ten pounds). Perfection in shape is seldom attained below seven pounds, but if it can be obtained in smaller compass so much the better.

He should have a round skull, and large, round, prominent eyes, with a deep indentation or "stop" between them. The lower jaw should project beyond the upper, and turn up. Large ears "touching the ground" are highly esteemed, but this is a figurative expression. They must droop close to the head and be thickly coated. The back of all the legs must be densely feathered, and the 
feet must be almost lost in the feather, which ought to project beyond the nails.

The tail should be carried low, the dog should stand on short legs and appear compact. Any protrusion of the tongue is most objectionable.

His coat should be silky, straight, very abundant, and of the richest color. The black should be intense, the tan vivid and rich. The dog should be altogether free from white. He should have tan of this rich red quality on his cheeks and the inner margin of the ear. His lips should be tan, and he should have a spot of the same color over each cye; the larger this spot is the better. His cheeks should be well tanned, also his chest or "mane," all his legs, his belly, the feather of his haunches, his vent, and the under plumage of his tail.

\section{TOY TERRIERS.}

Each variety of the terrier, when bred less than five, or even seven pounds, is considered to belong to the toys. If a black and tan, the colors should be very distinct and rich, without a speck of white, and on the tan each toe should be penciled with a fine streak of black reaching to the knee. This is a point greatly insisted on by fanciers. Blue and fawn smooth terriers are also prized highly. Smooth white terriers should be without a speck of color. These dogs have generally their ears clipped, with tails left perfect. The rough blue fawn, silky coat terrier makes a very pretty toy dog, so does the dwarf bull-terrier, both resembling the larger breeds in all points. 


\section{JACK0, THE WONDER.}

One of the most remarkable black and tan terriers, of his time was the late dog "Jacko," called the Wonder, owned by the genial Jemmy Shaw. In Jemmy's darkest days, when misfortune followed misfortune and everything looked black, he started from London with no other companion than his dog, and visited various parts of England, entering Jacko for all kinds of ratting matches, and a number of contests with other dogs, and carrying off silver collars, goblets, watches, rings and money prizes, more than enough to keep Jemmy, and enabling him always to have a little ready money. Joe Carless, the rough and ready but whole souled publican of Paterson, N. J., will bear me out in all that can be said about Jemmy and Jacko. When Jacko was hardly able to stand and all but blind, I have seen him pitted against young dogs, and never but with victory on his side. Jemmy's voice seemed a charm, whether to hurry or check him, Jacko obeyed his master, tottering and sightless. In his old age and decrepitude I have often seen Jacko on a cold morning sit, first warming one paw and rubbing it over his face, then the other, till his nose was warm, and then turn round his tail to the fire; and being thoroughly warmed through, laid down and stayed there. He was one of the fixtures of Jemmy Shaw's parlor at the "Wrekin Tavern," in Broad,Court, London, where he ended his days about two years ago. Models in plaster and models in wood were numerous of Jacko. His portraits were printed in books and papers, and the dog was publicly exhibited at the Royal Crystal Palace on the 7 th and 9th of July, 1866, and met the admiration of above 50,000 visitors. His master, Jemmy Shaw, was presented. with a valuable large silver goblet by the directors of the Crystal Palace, also a handsome medal as a lasting memento.

Jacko was a thirteen pound dog, and won nearly four hundred matches; he was only defeated five times, viz.: by Old Nell, when he was greatly out of condition, also by Young Dutch, Portsmouth Toby, Hopping Clara and another dog, name unknown. In 1861, in the Potteries, Staffordshire, Jacko killed twenty-five rats in one min. twenty-eight sec.; which is the best time on record. In 
July 8,1862 , killed fifty rats in three min. sixteen sec. On May 1, 1862, he killed one hundred rats in five min. twentyeight sec. The shortest time on record for that number, completing the unprecedented feat of destroying one thousand rats in one hundred min. with time to spare. On June 10,1862, he killed two hundred rats in fourtecn min. thirty-seven sec., the time never having been beaten. The above are only a few matches to show his extraordinary ability at rat-killing.

\section{DOG SIIOWS.}

We have our horse, cattle, bird and even baby shows, but very little attention has been paid to dog shows. Why not is a puzzler, for it is in the power and means of almost every one to keep a dog of some kind, and as a natural consequence one would expect more general interest to be felt in this direction than in the others mentioned. In England, more especially in London, dog shows have always been and still are an institution, and if not participated in so much by the silver spoon born order of society, they are nevertheless a good thing, serving to encourage and foster the breeding of pure and perfect specimens of the cinine race. Bull dogs, terriers and toy dogs are the principal varieties shown, and there one sees them to perfection. Bell's Life of the present day has a column devoted to dog shows, wherein prizes are offered to the shortest nosed bull dog, the smallest black and tan, Scotch, Skyo and Maltese terriers, which varieties seem to be most popular among the sporting element from their beauty, perfection and pluck. Men supposed to be brutal in their nature are found to take far more care of their little pets than they do of themselves. There is material enough for the same kind of dog shows here, and perhaps at no late day our dog fanciers may form some kind of an association with this object in view. Messrs. Butler, Dovey, Young, Silvey, Fletcher, Jennings, Walton and others who make a speciality of dealing in dogs, to say nothing of thousands of private individuals who own choice specimens, have a variety and stock sufficient to compete with all comers, and they would find it to their mutual interest to establish a National Dog Club. 


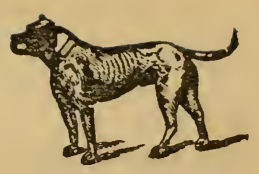

\section{TRAINING FOR THE PIT.}

BY ED. JAMES.

In matching a dog, you should be guided by the condition of your dog whether you match him to fight in 4,6 or 8 weeks; if he is fat, you must allow from 6 to 8 weeks. To get him in condition, commence by cleaning him well out inside. You can do that best by giving him magnesia in his food, say a tablespoon each day, for 4 days. Get some sheeps' heads or calves' feet and boil till you can shake the bones out and leave the meat. Take bran from wheat and scald it, then mix the bran and the soup together and feed to the dog, cold. Feed on that for 2 or 3 weeks, according to the time you have got to put him in condition; he should not be fed on hard food more than 2 weeks. The last 2 weeks you must get good rump be $f$ steak and broil it, very rare, then take bread and slice it and toast it dry, mix the dry toast with the steak, cut very fine. Do not give him over a tea-cup full of water each day, and if you find he is feverish and wants water, get one quart of Irish moss and boil it in 2 quarts of water, strain it, and give about a tablespoonful of the liquid when you feed, night and morning. When you commence to work your dog, give him about half an hour's work at a time and increase his work as you go along. You can judge how much to feed and how much work he ought to have to do. Do not work him too much, one hour's hard work is enough for any dog. If he works good for one hour, he will fight 3 hours. If he does not lose flesh fast enough for you, do not feed him so much. A dog should not be taken down too fast, one pound a day to start with, and less as you come near fighting. You must weigh your dog before and after work, so as to know exactly how he gets along.

When you have given him his work, rub him well from the point of his nose to the end of his tail, also his legs and his breast-rubbing with the hands surpasses the brush, towel, or anything of the kind; in case the dog needs washing, do so with alcohol, and be sure to rub him dry with the hands.

It may be as well to caution all interested in reference to the poison frequently rubbed on dogs to prevent the opposite dog from biting, which is generally in the form of Conrosive Sublinate, hence the impor ance of taithful handlers and trainers. The same course of training laid down above will answer also for dogs matched to kill rats for money or prizes. 


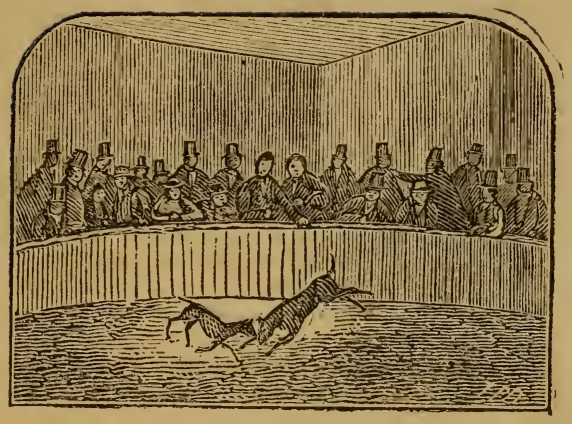

\section{DOG FIGHTING RULES:}

RuLE 1. To be a fair scratch in turn fight.

2. Both dogs to be tasted before and after fighting, if required.

3. Both dogs to be shown fair to the scratch.

4. Both seconds to deliver the dogs fair from the corner, and hot leave until the dogs commence fighting.

5. A time-keeper to be chosen in the pit; half-minute time to be allowed between every fair go away; twenty-five seconds allowed for sponging; and at the expiration of that time the timekeeper shall call, "Make ready," and as soon as the half minute is expired the dogs to be delivered, and the dog refusing or stopping on the way, to be the loser.

6. Should either second pick his dog up by mistake, he shall put it down immediately or the money to be forfeited.

7. Should anything pernicious be found on either dog, before or after fighting in the pit, the backers of the dog so found to forfeit, and the person or persons holding the battle money to give it up immediately when called upon to do so.

8. Two umpires and a referee to be chosen in the pit before fighting; in case the umpires should not agree, the decision of the reteree to bo final.

9. Either dog exceeding the stipulated weight, on the day of weighing, to forfeit the money deposited.

10. No dog shall scratch to a dead dog; when one dog is dead the living one wins the battle.

11. Both dogs shall be washed or sponged from the same tab, so as to prevert cither party introducing deleterious drugs or poisons in the water. 


\section{ENGLISH DOG FIGHTING RULES.}

1. Both the dogs to go to scale, neither dog to exceed a certain weight, on penalty of losing the battle money. Color to be named in the articles if required. Time keepers, two umpires and referen to be chosen agreeable to both parties in the pit. The pit to be from ten to twelve feet square, with white scratch marks or scratch corners, say about two feet size in opposite corners, termed scratch marks.

2. The dogs to be tasted or tried if any pernicious rubbing or fakeing the dogs. If so, by the direction of the referee the dogs to be thoroughly washed clean, or by his decision to forfeit all claim to the stakes; the dogs to be tasted and tried before and aft:r setting-to if required, to be decided by the referee; two buckets of clean water to be mixed and toss for choice in the pit.

3. 'To toss for choice of corners and each dog to be loosed in a fair style by their seconds. The dog that makes the first fault-that is, that goes away first-to be the first to scratch, or to go in, providing he is picked up at the time of his first fault or go away; then each dog to scratch in turn alternately, no matter which makes the fault or go away. After the first go away each dog to scratch in turn, the dog that scratches last to be declared the winner. If either dog be so distressed as not to be able to mouth the other, but to go to the opposite scratch, the dog whose turn it is to go in must go all the way across without stopping. To constitute a fair go in, his fore feet must touch the opposite scratch.

4. Neither seconds to touch either dog, or behave unfair to either dog or second in the pit. If so, by the appeal and decision of the referee to be disqualified, either second throwing his dog across the pit to be deemed foul. Stamping on or near the dog's head to be deemed foul. If picked up in a mistake, to be put down again and fairly fought out. Unless if picked up intentionally foul, to be decided by the referee.

5. To constitute a fair go-away or picked-up, both dogs to be free of each other, both their heads and fore feet from the other; the second of either dog to watch minutely, to pick his dog up when he moves away as above. If while picking up either dog should catch hold of the other, the second to put his dog down again and fairly wait for a fair go-away and pick up. This rule to be strictly adhered to, and if any dispute arises to be appealed to the umpires and referee, and the referee's decision in all such appeals, right or wrong, to be binding on all occasions. None but experienced judges should undertake such unthankful offices, and to be agreed to by both parties. When the seconds pick up their dogs, to go to their respective corners and wash and sponge their dogs' mouths. One minute to be allowed for time, the time keeper to call out aloud at forty-five seconds, "Hands out of the pit." At fifty seconds, "Get ready." Both dogs to be shown a fair head at the scratch. At sixty seconds' call, "Time,"let go, the time keeper to observe, "It is your turn to go in," naming $d o g$ and master.

6. Each party to be allowed a friend agreeable to both parties, to be a silent observer in each corner, but to be kept a respectful distance from either dog, water, \&c. If any unfair chicancry on either side is suspected, to be decided by the referee. 


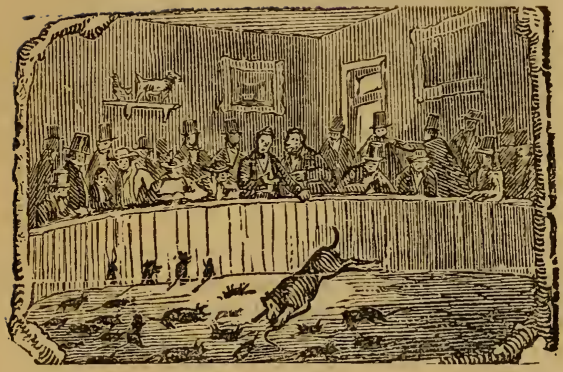

\section{- RAT KILLING RULES.}

(EITHER FOR MATCHES OR PRIZES.)

1. Each dog to kill as many rats as he (the said dog) weighs pounds.

2. Any dog exceeding one quarter of a pound over the pounds he weighs is to kill one rat extra, unless otherwise agreed on.

3. The name of the owner, the color, name, \&c., of the dog, weight and number of rats they have to kill must be written oz separate slips of card and put into a hat or can.

4. A referee and a timekeeper to be appointed, with a stop-watch, and another person to look over him, the time to be kept by one watch only; and in case of any dispute, the decision of the referee to be final.

5. The smallest number of rats are to be put into the pit, a card is then to be drawn from the hat or can, and the number of rats named on it to be announced, and the rat catcher is to make up the number (if any is required), when the name of the owner and of his $\operatorname{dog}$ is to be announced.

6. The second is to let the dog go when the timekeeper is ready to take the time by anyone that may be agreed on.

7. The second is not to touch the dog or rat until he considers the rats are all dead. He is then to pick up his dog and call time dead, the timekeeper to stop his watch and announce the time. N. B. - If the second infringe upon this rule by touching the dog or rats for any purpose, the releree shall adjudge the dog to have lost the match.

8. If the owners of any dogs engaged in the match (but no other person) consider that the rats are not all killed, or that the second has picked up his dog foul-that is, he has taken up the dog before he had bitten all the rats-he is to appeal to the referee; and if he (the referee) considers that ho has done so intentionally, the said 
dog to be excluded. N. B. - If the referee considers that it is not a foul pick up, but that the rats are not all dead, he is to point them out; and if there is any doubt, the second is to tread on their tails, and if they crawl their whole length they are to be considered live rats, and the dog is to be put down again to kill them.

9. The dog is to be held in the middle of the pit, in a marked circle. When the timekeeper is ready he is to be let go, and the time he takes to kill them is to be added for the first time.

\section{RULES FOR MATCHES.}

1. The owner of each dog to provide, at the time named in the agreement, the number of rats that his dog is to kill.

2. Half of each person's rats is to be put in the pit, and then toss for choice of rats; and if the winner of the toss chooses the rats that are in the pit, his dog is to kill the first.

3 . If one rat catcher finds rats for both parties, the rats (if possible) are all to be put in one cage; and the number of rats the first dog is to kill is to be put into the pit, when the parties are to toss for ehoice of rats, and the same proceedings to be observed as in Rule $2 \mathrm{~d}$, unless otherwise agreed on.

\section{RULES FOR HANDICAP MATCHES.}

1. Each dog must kill an equal number of rats to the number of pounds he weighs.

2. A five pound dog to kill five rats; a ten pound dog to kill two rats extra; a fifteen pound dog to kill three rats extra; a twenty pound dog to kill four rats extra; a twenty-five pound dog to kill five rats extra, or one extra rat for every additional five pounds weight.

3. Any dog weighing one, two, three or four pounds between any of the above weights, one second of time shall be allowed to the time he kills his quantity of rats in; for instance, a seventeen pound dog kills three rats in fourteen seconds, he is to have two seconds added to his time, because he weighs serenteen pounds, which is two pounds above the specified weight, viz.:-a fifteen pound dog to kill three rats, and so on in the same proportion.

\section{BADGER BAITING RULES.}

1. The badger or coon box should be at least seren feet long, about sixteen inches high and one foot wide, with no turn in the end of it.

2. A dog must draw the coon or badger's head to the front inside of ten seconds, to count a draw.

3. No dog is allowed to run twice or to be sponged. 


\section{THE RAT.}

\section{ITS NATURE AND FECUNDITY.}

Rats are accredited by a philosopher to be one of the most fertile causes of distress. None of the naturalists give a clear explanation of the rat; they give a most lucid description of him as he is; but as to what he does, is most vague and imperfect. Rats feed and labor in the dark; they shun the approach of man. If we go into a barn or granary where hundreds are living, we shall not see one, unless we disturb them in their hiding places; and if we dive into a cellar that may be perfectly infested with them, we shall not see any, unless it may be a stray one popping across for a more safe retreat. Consequently, men seldom think of them, because they seldom see them; but if rats could by any means be made to live on the surface of the earth, instead of holes and corners, and feed and run about the streets and fields in the open day, like dogs, the whole nation would be horror-stricken, and ultimately there would not be a man, woman or child able to brandish a stick but would have a dog, stick, or gun for their destruction wherever they met with them.

Rats are said to live in open warfare, and to destroy each other for the sake of cannibalism. This is an erroneous notion; for so far from that, they live by hundreds and thousands in a community. They are, in the strictest sense and substance of the tern, true Communists or Socialists, living in opsn intercourse and in common with each other, and wallowing in laziness and luxury stolen from the stores of industry. When they run short of food, they will migrate hundreds in a drove to some neighboring barn, granary, or what not-no matter where; for where corn is, there will they resort, and no one thing is proof against them save solid stone or metal.

Messrs. Jemmy Shaw and Sabin of London, Ing. are said to have destroyed between eight thousand and nine thoursand pairs of rats each, annually, averaging seventeen thousand pairs between them. Rats will have six, seven, and eight nests of young in the year, and that for three and four years togetier. They will have from twelve to twen- 
ty-three at a litter, and the young will breed at three months old. There are more females than males, at an average of about ten to six.

Four litters in a year, beginning and ending with a litter, so making thirteen litters in three years; to have eight young ones at a birth, half male and half female; the young ones to have a litter at six months old.

At this calculation take one pair of rats; at the expiration of three years you will have six hundred and forty six thousand eight hundred and eight!

Mr. Shaw's dog "Tiny," under six pounds weight, has destroyed two thousand five hundred and twenty-five pairs of rats, which, had they been permitted to live, would, at the same calculation and in the same time, have produced one thousand six hundred and thirty-three millions one hundred and ninty thousand two hundred living rats!

And the rats destroyed by Messrs. Shaw and Sabin in one year, amounting to seventcen thousand pairs, would, had they been permitted to live, have produced, at the above calculation and in the same time, no less a number than ten thousand nine hundred and ninty-five millions seven hundred and thirty-six thousand living rats!

\section{HOW MUCH RATS CONSUME.}

First, six rats will consume day by day as much food as a man; second, that the thing has been tested, and that the estimate given was, that eight rats would consume more than an ordinary man. To place the thing beyond the smallest shadow of doubt-set down ten rats to eat as much as a man, not a child; nor say anything about what rats waste, and the result is that the first pair of rats, with their three years' progeny, would consume in the night more food than sixty-four thousand six hundred and eighty men the year round, and leaving eight rats to spare! And the rats destroyed by the little wonder "Tiny," had they been permitted to live would, at the same calculation, with their three years' progeny, have consumed as much food as one hundred and sixty-three millions three hundred and nineteen thousand and twenty men; above two-thirds the population of Europe!!

And now for the vermin destroyed by Messrs. Shaw and Sabin. Taken at the same calculation, with their threa years' progeny, they would, it is argued, consume more 
food than the whole population of the earth. The population of the earth, including men, women and children, is estimated to be nine hundred and sevcnty miliion souls; and the seventeen thousand rats in three years would pruduce ten thousand nine hundred and ninety-five millions seven hundred and thirty-six thousand; consequently, at ten rats per man, there would be sufficient rats to eat as much food as all the people on the earth, and leaving one thousand two hundred and ninety-five millions seven hundred and thirty-six thousand rats to starve. So that if the human family were increased to one thousand and ninetynine millions five hundred and seventy-three thousand sir hundred, instead of nine hundred and seventy millions, there would be rats enough to eat the food of them all!

In some parts of England men make their living by catching rats and selling them, and as much as $\$ 1,000$ a year is said to have been paid by one London dog-fancier. Every rat is brought up from the country fresh and clean, or they would not serve their purpose.

If a farmer has only ten rats upon his farm, he is keeping equal to one man in idleness; if he has a hundred rats, he is keeping equal to ten men in idleness; but if he has a thousand rats upon his farm, to say nothing about mice, (and few large farms have much less), he is keeping equal to a hundred men in idleness the year round.

Rats are only good to manure the land with their dead carcases, since they afford neither food nor raiment for man.

\section{ABOUT FERRETS.}

The rats' enemies are the ferret, cat, dog and the man. Ferrets are bred for rat and rabbit hunting. They should be kept very hungry when wanted for hunting, because they will hunt but very little, if at all, when they are weil fed. Consequently, they hunt, not for the purpose of destroying their victims, but for the sake of getting a meal ; and when they are put into the holes, if they should slip their muzzles and catch a rat or rabbit, or come across a nest of young ones, they will destroy them; and aftc1. they have gorged as much as they please, they will frcquently lie down by the remainder, and go fast to sleep.

WHAT CATS AND TRAPS WILL DO.

Some cats are determined creatures; they will watch for 
Clays together for a rat; sometimes they catch him, and sometimes not. On the other hand, rats have leen noses, and can smell the cat; so they will shift their quarters to some other place of greater safety.

Some persons use traps, but to little purpose. The secret is this: rats are by nature very clean animals; consequently, when traps are new and sweet, rats may be decoyed into them; but when they have had a rat or two confined and fretting in them, they become so foul and offensive that another will not go near them; so that the traps, to be made useful again, should be put in soak for twentyfour hours, and then hung up in the air for a week to become sweet.

\section{MAN'S BEST FRIEND, AND RAT'S GREATEST ENEMY, THE DOG.}

The dog will protect his master both by night and day from thieves of every denomination; nothing can shake his fidelity, and all he requires in return is a crust and a friendly pat; with these he feels himself amply rewarded, and will exert every faculty nature has endowed him with to serve and amuse his master. The most merciful and speedy way of destroying rats is to let the dogs kill them. The little wonder "Tiny" has twice killed two handred rats within the hour. Other large dogs will kill from eight to twenty rats in a minute.

Let all persons who feel an interest in the destruction of vermin use their utmost endeavors to patronize and propagate the breed of small terriers. A dog, to be of sound service, ought to be from six to sixteen pounds weight; over that they become too large and unweildy for the purposè, and too expensive keeping; besides little dogs will kill mice as well as rats, and that is a great recommendation. The rat-killing terrier is as hard as steel, courageous as a lion, and as handsome as a race horse.

\section{HOW TO LEARN DOGS TO KILI RATS.}

A bull terrier or bull dog should be at least six months old before a rat is given to him to kill, and a small bred black and tan, Scotch or skye-terrier from nine months to a year. If thoroughbred, at this early age a terrier pup of any kind will take to killing as natural as an old ratter. 
In all cases, the teeth of the rat should be pulled out with nippers, or his jaws tied up, at least the first half dozen c: dozen should be server in this way, to prevent their biting the pup, as if bitten at the first attempt it will take the dog a long time to forget it.

If possible, give your dogs barn rats, or those fed on grain, as hotel rats or other high fed "varmints" often times sicken the dog after biting them from the greasy nature of their food.

\section{ART OF \\ LEARNING DOGS TRICKS.}

One has only to go to a menagerie of perfoming wild beasts and see the most ferocious and savage denizens of the forest, under almost cat-like subjection, to be assured how comparatively easy it must be to teach your dog lots of little arnusing tricks. Newfoundlands, Black and Tan Terriers, King Charles Spanicls, Pomeranian or Spitz Dogs, Scotch, Skye and Maltese Terriers, and the French Poodle are, as a general thing, the most intelligent and easily learnt. The Newfoundlands have been made stageheroes, and earn from $\$ 50$ to $\$ 150$ per week according to their ability as actors. The salary of a good performing Poodle averages $\$ 150$ per week. The half-bred, ill-fed, blind man's dog, if not good at tricks, will lead his master through all kinds of dangers and bring him home when no longer able to beg and the streets become deserted-his pay is small but such is his fate. Dogs, like men, are born to good or bad luck.

It is not our province here to give anecdotes of dogs. Neither space nor policy admits of it, as there are already many books in the market treating on these matters at large. In undertaking to learn dogs tricks, it should be commenced from the time they are three months old, and it should be borne in mind that your own patience and perseverance has as much to do with it as anything: Use firmness and kindness before kicks and cuffs; in fact, do pretty much the same as you would wish to be done by 
yourself. We are indebted to "Haney's Art of Training Animals" for the modus operandi of the following tricks:-

To Leap. $-\Lambda$ line or pole may be extended frnm any convenient supports, just so high that the dog cannot step over. Take your station on one side of this barrier with a supply of bread or cracker. By the offer of a small piece induce him to approach as near as possible to the line or pole keeping the tid-bit close to his nose, but raised a trifle above it. Now, with a sudden movement, extend your hand beyond the barrier, crying at the same time "hip," or any other quick, inspiring exclamation. Eager to get the tempting morsel he will leap over, and the same proceeding may be repeated once or twice, when he should be rewarded with the bait he has been striving for. After a few repetitions he will probably leap over at a motion of the hand and the word of command. He should always be rewarded for obeying, and it is well to have a light switch with which to give him a gentle cut should he attempt to run under, which he should never be permitted to do. The hight of the barrier may be increased gradually from day to day, taking care never to overtask his powers.

When the dog leaps readily over a bar, a hoop may bo held in the hand and the same system pursued. The hoop may be gradually lessened in size until the dog finally leaps through one hardly bigger around than his own body, but to do this the trainer must display some skill in conforming the motions of the hoop to those of tho dog as he passes through.

To WaLK ERECT.-Hold a bone or other like temptation a little above the dog's nose, but not so high as to lead him to jump to get it. As he reaches for it raise it so as to induce him to raise up on his hind feet, saying as you do so, "up, up!" When he reaches the proper stand-point, let him remain there a moment or two and then let him have the bone. Soon he will stand up on your merely holding your hand in the position described and saying, "up, up." Then he may be taught to walk in this position by slowely movirg the bone or your hand slightly in advance. These exercises should not be tediously prolonged, especially at first, for the position is an unnatural and fatiguing one to the animal. After he thoroughly understands what is required of him you may check any attempt 
he may make to regain his natural position before you are willing, by a gentle tap under the chin or under the fore paws.

To Daxce.-A dog is generally considered sufficiently' accomplished in this "graceful and agreeable art" when he has learned to hop around on his hind legs, and to keep turning completely around at short intervals. Take a long switch, after the dog has learned to stand erect, and to this switch attach a piece of meat. With this you can trace out in the air, in tempting proximity to his nose, the figures you may wish him to take, and you may depend upon his instinct leading him to follow the motions of the switch. The dog should be rewarded with the meat after he has danced enough to fairly earn it, and after a few lessons the switch may be used without any bait attached. He will at first follow its motions in the hope that there is something attached, and if he be rewarded for doing so, he will soon comprehend that following the switch means meat by-and-by.

To Sit and Lie Down.-Taking your position with the dog in front of rou, raise one hand over his hearl and make a motion with it as though about to strike lim on the top of his head with your palm; as you do so repeat the word "down" distinctly and commandingly, with each motion of the hand. This should not be done as a menace, but to indicate your wishes. Thile you do this, press firmly with your other hand upon his back, just over the hips-this pressure will assist in making him take the desired position. When he has done so he should be patted and made to understand that he has done right. Repeat until he obeys the command readily, and then teach him to lie down, which consists in forcing him into a recumbent posture, as you command him to "lie down!"

To BeG.-After the dog has learned to stand erect he may easily be taught to beg. All that is requisite is to press him down in the required position; if he attempts to leave it a gentle tap on the head with the switch will bo sufficient to control him. He may, if preferred, be taught to beg without learning to stand erect; in this case he may be made to sit down and then, pressing his haunches down to prevent his rising to his feet, tap him under the chin till he takes the right position. Repetition is of course neces- 
sary until he learns what is desired, and each time you place him in position it is well to say "beg" two or three times so he may associate the word with the act.

To Speak For Ir.-Take a piece of some article of food which he is fond of, and allowing him to sse it, command him to "speak for it." - Of course he will not understand what you mean, and will probably only gaze wistfully at the morsel. By and by he will grow impatient and give vent to a sharp bark. The moment he has done this give him the article, for although he has not understood you he has done what you desired, and by rewarding him he learns that this is the case. Practice him a little at some of his old tricks with another reward at hand to encourage him. Should he try the experiment of barking while thus engaged no notice should be taken of it, for it is not desired that he should bark except he be told to, and his doing so in other cases should never be rewarded. When you wish it, repeat the command of "speak for it," and when he obeys reward him. If at first he does not show an inclination to bark he may be stimulated to do so by your giving: a "bow wow" yourself in as doggish a manner as you are able.

To Fetcr and Canry.-Place the article in the dog's mouth, and when he lets go of it give him a slight box on the ear and replace the article in his mouth. Whatever is given him to carry should be of such a form as to be grasped easily by him without hurting his mouth or teeth. The weight should at first be very light, and never more than he can easily carry. Most dogs will take a real pleasure in carrying articles in this manner, and they seem to feel the responsibility attached to their duty, for they will earry their own or their masters' dinner without attempting to appropriate any portion of it until the proper time when their share shall be given them. In teaching dogs to carry food, however, it is necessary to take a little special pains to overcome their instinctive inclination to eat it. A good, plan is to place the article in a covered basket which they cannot open, and when the dog has learned to carry an ordinary parcel give him this. If he attempts to get at the food, which he readily detects by his sense of smell, bax his ears. By-and-by reward him with the food, and then try him with a basket from which he can abstract the con- 
tents; if he tries to do so punish him slightly, never permitting him to steal the food.

To make a dog carry articles from one person to another it is only necessary for two persons to take their positions at some distance from one another. One gives the dog some article saying, "go, sir," at the same time. As the first says this let the other person call or whistle to the dog. Now let this one give the dog some thing and let the other call him, and so on back and forth until he will go from one to the other at the command, "go, sir." The distance between the parties may be increased from time to time, and the trick may be varied by one of them hiding himself, this will teach the dog to hunt for the person to whom he is to deliver the article, which will prove useful when you by-and-by desire to send him on an actual errand at a distance.

It is not very difficult to teach a dog to go on errands. Suppose you wish him to go to the store for you of a morning; take him with you regularly for a few mornings, letting him carry the basket. In a few days he will understand when you start where it is you propose to go, and will, perhaps, run on ahead and arrive there some minutes before you. It would be well on all occasions before starting to give the command, "Go to the store," which will accustom him to it.

To Bring His Tail In His Moute.-The dog having been taught to fetch and carry, an amusing application of this knowledge can be made by having him bring his own tail in his mouth. The feat is rather difficult, for while his tail is in his mouth, the dog can only advance in something: like crab fashion, or sideways, with an almost irresistible tendency to go around in a circle without getting ahead any. T'o attain success in teaching this trick the dog must be gifted with a good deal of tail, and the trainer with a good deal of patience. Dogs will in play grasp their tails, and most persons have noticed while frolicking with a dog that if the dog's tail be taken hold of with one's hand, the dog will attempt to seize the hand with his mouth, and if his tail be now dexterously placed in his way, he will seize that. When the dog takes hold of his tail praise him, and after he has held it a little while bid him "let go," and reward him. Should he relinquish his hold before you order him to, speak sharply to him and commence again. 
When he has learned to retain hold of his tail until ordered to relinquish it, the more difficult part of his lesson may be taught-the bringing it to the trainer. The trainer at first takes his place a few feet from the dog in the direction in which the dog can most easily advance, and calls the the dog; should he let go his tail to come, he is to be scolded, and the tail placed in his mouth. When he comes without letting go, he should be rewarded. Gradually the distance he is required to come may be increased, but it it would be cruel to make the distance more than half a dozen yards. When the tail is placed in his mouth it is well to say "Bring me your tail," to accustom him to the order. By-and-by when you give this order merely hold his tail for him to grasp, and at last let him seize it without any assistance from you.

To Stand on his Head and to Walk on his Hind Legs.The term "Standing on his Head" is applied to a "wrong end up" position, the animal is actually supported by his fore paws, his head not necessarily touching the ground. To teach the trick, provide yourself with a switch twenty inches in length and moderately stout. This switch, held in your right hand, you place under the dog's belly, and while you raise up his hind quarters with it, you place your left hand on his head to prevent him from moving away, and to make him retain his reversed position. As the dog rises into position the switch should be gradually carried along until it supports his hind feet. This is the process for the first few lessons, until the dog understands what is required; after that it is better merely to tap his ankles in front with your switch, giving at the same time whatever order you have accustomed him to in teaching the trick. He should eventually take the position without any hint or help from the switch.

When the preceding trick is thoroughly mastered, the walking part may be easily added. Taking your position a little in front of your pupil when he is in his upsidedown position, you encourage him to come to you. At the same time you must keep your switch in handy proximity to his toes, which you tap lightly on any signs of his relinquishing the position.

To "Sinc." - When a dog howls in time, we think it fair to call his performance "singing:" The dog should be 
kept without food until his appetite is quite sharp. When food is shown him he naturally whines for it. Now a dog may be marle to whine, howl, or bark, if you make any of these noises yourself; almost any dog will imitate you, and not only that, but the pitch and style of noise he makes will be somewhat regulated by that made by you. The hungry dog is in prime mental condition for this exercise, and if rewarded when he hits pretty near upon the right degree of noise, he will learn to follow your tones quite accurately. If exercised in a regular scale, or in a simple tune, he will by-and-by go through it without requiring your prompting, with sufficient accuracy to be recognized-if the hearers know beforehand what melody to expect.

It is not pretended, of course, that dogs trained as above described, do anything but repeat a series of noises mechanically in a prescribed rotation.

To Feign Death.-A dog may be placed on his back or in almost any other posture, and by speaking' sharply to him and threating him with your forefinger, you can prevent his changing his position. In this manner the trick of feigning death is taught. If a special word of command be used when placing him, he will learn to take the position on hearing that command.

The Lump of Sugar Trick.-Tbis consists in placing a lump of sugar on the dog's nose, and having him toss it up and catch it in his mouth. It is not essential that sugar should be used; any other dainty will do as well, indeed a piece of meat will answer better in teaching the trick. In teaching, hold your switch under the dog's chin, and tap him whenever he tries to lower his head to let the meat drop. If he does not presently jerk his head up, and so throw the morsel into the air, you should strike him a pretty smart rap under the chin to make him do so. When it leaves his nose there will be no instruction required to make him seize it promptly before it has a chance to reach the ground; should it, however, touch the ground, it is well to take it from him and make him toss it again. 


\section{DISEASES AND THEIR CURE.}

HYDROPHOBIA, OR CANINE MADNESS.

Symptoms:-Restlessness, countenance anxious, eyes bloodshot, snapping at the empty air, his natural food is neglected, at the same time every sort of filthy trash is greedily devoured; eating his own excrement is an carly symptom. He also has an insatiable thirst.

Treatment.-The dog should be at once destroyed.

\section{INFLAMMATION OF THE EYE.}

Treatment.-Bathe the dog's eyes with cold tea two or three times a day.

In blindness, wash with a lotion of sulphate of zinc four grains, sugar of lead four grains and distilled water half a pint twice a day.

\section{CATARACT, OR SCUM.}

Treatment.-Take pulverized white sugar, common barley sugar is the best, open the lids and fill the eye three or four times a day, or blow the sugar through a quill into the eye.

\section{INFLAIMIATION OF THE BOTVELS.}

Symptoms.-Dullness of appearance and eyes; loss of appetite; lying on the belly, with outstretched legs, pulse much quickened; scratching up of the bed into a heap and pressing the belly on it; desire to swallow stones, coal, etc.

Trealment.-Bleed most freely, till the dog faints away. Clap a blister on the pit of the stomach. Give aloes, fifteen grains, and cpium, half a grain. Repeat dose three times a day. Bleed after twelve hours, if pulse rises again, and continue dosing and bleeding till either the dog or inflammation gives in.

\section{DUMB MADNESS.}

Symptoms.-Stupidity; restlessness; the tongue becomes of a dark color, and much swollen; the animal is also constantly rubbing its jaws with its paws, as if seeking to 
remove a bone from its throat; and is in general unable to keep its mouth shut, or the tongue within it.

This disease is incurable.

\section{CANKER IN THE EAR.}

Symptoms.-Shaking the head, holding it on one side, and violent scratching of the ear.

Treatment. - The ears should be well washed with warm water and soap, and then syringed out with a solution of sugar of lead, in the proportion of about a teaspoonful of the lead to a pint of distilled or rain water. The washing should be repeated twice or thrice claily, and the bowels of the dog kept open by a daily laxative; if these remedies fail, a seton must be run through the back of the neck, and strong doses of aloes given every second day.

\section{JAUNDICE.}

Symptoms.-The white of the eye becomes suffuse i with a yellow hue, and the same hue spreads over all the skin; nose and mouth are dry and parched; the dog loses appetite; seeks concealment; becomes weak and emaciated; vomits greenish matter, sometimes tinged with blood; loses consciousness.

Treatment.-Give Epsom salts, combined with mucilage of gum Arabic, or very well boiled gruel. If you think the disease has only just made its appearance, an emetic will be of great service, and common salt will answer the ptirpose, if nothing else is at hand. Small doses of calomel and colocyith, in the form of a pill, given at night, and followed by an aperient in the morning, will generally prove sucsessful. If much fever be present, bleeding should be resorted to.

When appetite returns, the food should be light, and given in small quantities.

\section{WORMS.}

Symptoms.-Fetid breath, voracity or total loss of appetite, violent purging, or obstinate constipation, wwith great emaciation, sometimes fits. One of the ordinary symptoms is the dog dragging his fundament along the ground.

Treatment.-Give, first day, a smail pill formed of Venice turpentine and flour, from the size of a very minute pea. to that of a small marble, according to the size and age of 
the pup. The former will suffice for Blenheim or King Charles pups, Italian greyhounds, \&c.; the latter for bloodhounds, Newfoundlands, mastiffs, \&c. The second day, give a small dose of castor oil; a teaspoonful to the smaller, a tablespoonful to the larger breeds; in neither case, however, quite full. Third day, give nothing. Fourth day, turpentine, as before. Fifth day, the oil. Sixth day, nothing; and so on.

Keep your puppies' beds dry, clean and sweet. Do not feed them too often, or on food of too nutritious a quality. Puppies should not be fed oftener than three times a day. The morning and evening meals may be given at $9 \mathrm{~A}$. M. and at 7 P. M., and should consist of vegetables-potatoes, oatmeal, \&c.-well boiled, and given with milk. At two, give meat with the mess, but not too abundantly. Between the meals give a drink of buttermillk, or millk and water.

Aloes are useful for dislodging worms from the rectum, as they pass down the intestines almost unchanged; but powdered glass is the safest and most efficacious; give it in pills formed with butter and ginger, and covered with soft papcr.

\section{MANGE}

Is of three kinds-the common mange, red mange, and scabby mange.

Treatment.-Common mange readily yields to cleanliness, with small alterative doses of sulphur and nitre given daily. If neglected it runs into scabby mange; the skin breaks out into blotches; the dog becomes emaciated; the belly hard and swollen; and death will sooner or later ensue. Use aperient medicine for a day or two; then for a week give the alterative medicines above mentioned; after which hare the animal well washed with scft soap and warm water; then rub his entire body with the following:-

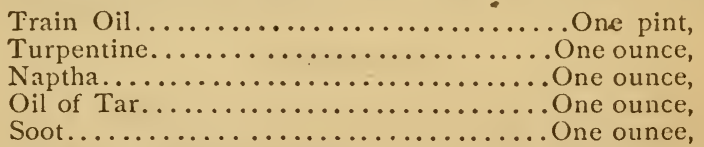

and Sulphur in powder sufficient to make the stuff of a proper consistence.

This is to remain on the dog for three days, during which time he must be kept dry and warm and fed spar. ingly; let it be washed off on the fourth day, with soff sosp and warm water, in. which some common washing: 
soda has been dissolved; give clean straw, plenty of exercise and cooling diet, and the dog will speedily get well.

In red mange a little mercurial ointment may be added to the above preparation.

Puppies are very liable to display a mangy-looking coat at the age of from two to four months. The hair falls ofi' in spots, and the skin becomes itchy, dry and scaly. This is not gennine mange, but if neglected is apt to run into it. At this early stage it is easily cured by washing with soft soap and water, and change of bedding, giving also a little sulphur in the food daily, and in very minute quantities.

Change of feeding is serviceable in the treatment of mange; but it is a mistake to suppose that this must always be to a reduced regimen.

Washing the dog with carbolic soap and hot water, three times a week, is another simple and very good ręmedy for mange.

\section{DISTEMPER.}

Symptoms.-Loss of appetite, dullness, fever, weakness of the eyes, a discharge from the nose, a short husky cough, discharge from both eyes and nose, a peculiar and fetid smell, emaciation, sometimes fits.

Treatment.-Bleeding is most useful, and that pretty copious; give an emetic, and follow it up by a gentle purgative; if-as is generally the case when the above treatment does not effect a cure-inflammation of the lungs supervenes, you must take more blood, give more aperient medicine, with occasional emetics. If the animal become weak, and is apparently sinking, give mild tonics, as gentian, quinine; and if he will not eat, put some strong beefjelly down his throat. A seton in the back of the neck is often useful, but should not be used indiscriminately.

\section{DIARRHCEA.}

Treatment.-Wait a day or two, to ascertain if the discharge will cure itself; if it continue, give castor-oil, with a few drops of laudanum.

\section{COSTIVENESS.}

Treatment.-Change the diet; give gruel and slops; and let the dog have full liberty; boiled liver will be found useful. If these measures fail, give small doses of castor-oil. 
Tie a ligature round his neck, and the vein will rise. Bleed the dog standing on his feet; when he droops his head, or appears weak, cut the cord; the bleeding will stop of itself without the aid of a pin.

Warts may be removed by the aid of caustic, and sometimes a ligature.

\section{ENCYSTED TUMORS.}

These are very common in the dog, and consist of small, soft bladders lying close under the skin, of a circular form and devoid of pain or inflammation. They vary in size from that of a pea to the volume of a small orange. The only remedy is the knife, which may be used with perfect safety by any one accustomed to it. The skin must bo saved and dissected back, and the tumor, when exposed, may readily be lifted out of its bed without much dissection; after which the parts may be suffered to heal of themselves.

\section{PARTURITION.}

In order to ascertain whether or not the bitch is in pup, a careful external examination will generally be necessary; when on pressing the fingers deeply between the rectum and the bladder, several small round or oval bodies may be felt, in number according to the future litter. Between the fourth and seventh weeks the whelps cannot be so easily felt; but, though they are said to be lost, a careful examination by a practiced hand will always detect nearly all of them lying close against them. After the seventh week they appear. very plainly, and the belly rapidly swells till it attains the size which it presents at whelping time; about three or four days before which the teats begin to swell, and on the day before are generally full of milk-a pretty sure indication of the near approach of labor.

Sometimes, however, her palvis is too small to allow of the passage of the whelp, and then either she must die, or man must afford his aid by mechanical means. If a part of the whelp is born, and the remainder does not come away for some time-owing apparently to the exhausted condition of the bitch-it is quite safe to give a little brandy and gruel by the mouth, and then steadily to draw away the whelp, by laying hold of the part prescnting with a picce of tape round it, or a strip of calico. 
As soon as all the whelps are born, the bitch may be allowed to rest a short time, unless she is very much exliausted, when the brandy and gruel may be given. After an hour, in the usual way, a little lukewarm gruel may be allowed; and in the course of four hours another quantity of the same. No meat of any lind should be given for three days, during which time the state of the bowels should be regulated, if necessary, by castor oil; and milk thickened with oatmeal or wheat-flour, or broth with the same thickening, or with arrowroot, if diarrhœe is present, should be the only fcod. Sometimes, after the first week, the whole litter is too great a draw upon the system, and part must be removed from the bitch, and brought up by hand, if it is wished to preserve them, feeding them from a common baby's bottle, with the India-rubber nipple now so commonly in use; but a very thick and stout one should be selected or the puppy will compress it too much with its tongre. When the bitch is much reduced by her suckling, she sometimes is subject to fits, for which the only remedy is the removal of her whelps, and the exhibition of strosg beef tea, with bark, and ammonia in addition; together with port wine and arrowroot, if the bowels are relaxed. After the first week, and, indeed, gradually during the fourth, fifth, and sixth days, meat must be added to the other food, especially if the bitch has had much animal food before whelping.

If the bitch is inclined to devour her young, she should be allowed to remain very quiet, and very little animal food should be given her. A dose of oil should always be given a short time before her whelping time; and if she should, nevertheless, devour them, another dose should follow, so as to carry off the effects of so heating a meal.

If a foster-mother is determined upon, all that is necessary is to muzzle her until the strange whelps have sucked her, and lain for some time with her own.

If the bitch has been "put by," as it is called, and is not in whelp at the end of nine weeks from her "heat," she will be fat and indolent, with her teats full of milk. At this time it is better to take a little blood from her, and to give her a smart purge once or twice, together with vegetable food; after which she will generally recover her health and spirits, and become much as usual at the expiration of another month or five weeks. 


\section{T王正}

GA M E C OC K: BEING A

\section{PRACTICAL TREATISE $\mathrm{ON}$}

BREEDING, REARING, TRAINING, FEEDING, TRIMMING, MAINS, HEELING, SPURS, ETC., ETC., ETC. TOGETHER WITH AN

EXPOSURE OF COCKERS' TRICKS, nim

ORIGIN AND CURE OF DISEASES, AND THE REVISED

\section{COCKING RULES}

GOVERNING ALL PARTS OF TIEE WORLD.

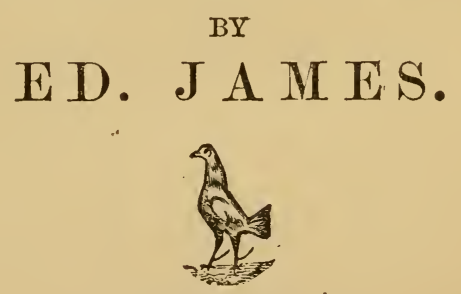

PUBLISHED $\dot{\mathrm{BY}}$

ED. JAMES, 88 AND 90 CENTRE STREET, N. Y NEW YORK CLIPPER BUILDING.

'CLOTH, GLT COVER, ILLUSTRATED, \$1.25. 


$$
x+y+2=0
$$








\section{LIBRARY OF CONGRESS

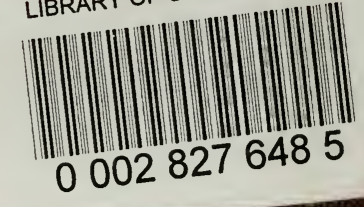

